\title{
Prevalence of Borrelia burgdorferi sensu lato in ticks from the Ternopil region in Ukraine
}

\author{
Marcin Weiner ${ }^{1}$, Wioletta Żukiewicz-Sobczak ${ }^{1}$, Małgorzata Tokarska-Rodak ${ }^{1}$, \\ Dorota Plewik ${ }^{1}$, Anna Pańczuk ${ }^{1}$, Marta Siłuch ${ }^{1}$, Jerzy Zagórski ${ }^{1}$, \\ Paweł Sobczak ${ }^{2}$, Tomasz Chmielewski ${ }^{3}$, Stanisława Tylewska-Wierzbanowska ${ }^{3}$, \\ Mariia Shkilna ${ }^{4}$, Mykhailo Korda $^{4}$, Ivan Klisch ${ }^{4}$, \\ Mykhailo Andreychyn ${ }^{4}$, Mariana Pavliuk ${ }^{4}$ \\ ${ }^{1}$ Pope John Paul II State School of Higher Education in Biała Podlaska, 21-500 Biała Podlaska, Poland \\ ${ }^{2}$ Department of Food Engineering and Machines, University of Life Sciences in Lublin, 20-704 Lublin, Poland \\ ${ }^{3}$ National Institute of Public Health - National Institute of Hygiene, \\ Laboratory of Rickettsiae, Chlamydiae, and Spirochaetes, 00-791, Warszawa, Poland \\ ${ }^{4}$ I. Horbachevsky Ternopil State Medical University, 46000 Ternopil, Ukraine \\ m.weiner@dydaktyka.pswbp.pl
}

Received: May 29, 2018

Accepted: September 20, 2018

\begin{abstract}
Introduction: Lyme borreliosis/Lyme disease is caused by Borrelia burgdorferi and is one of the most common vectorborne diseases transmitted by ticks. Material and Methods: A total of 136 Ixodes ricinus ticks, collected in the Ternopil (Ukraine) region, including 126 adults (70 females and 56 males), and 10 nymphs were examined. The identification of the species and their developmental form was based on morphological characteristics. Results: PCR with B5S-Bor and 23S-Bor primers resulted in Borrelia burgdorferi sensu lato DNA amplification among six ticks (4.4\%). The detailed analysis based on the DNA sequencing showed the presence of DNA of Borrelia afzelii in four samples; the remaining two represented Borrelia burgdorferi sensu lato complex, although their genospecies were not determined. The research confirmed the dominance of Borrelia afzelii genospecies in the ticks from Ukraine. Conclusion: It seems reasonable to undertake similar research in ticks from other regions of Ukraine. Knowledge in this field can be useful for public health and planning the prevention of tick-borne diseases.
\end{abstract}

Keywords: Borrelia burgdorferi sensu lato, Ixodes ricinus, genospecies, ticks, Ukraine.

\section{Introduction}

Lyme borreliosis/Lyme disease (LB/LD) caused by the spirochaete Borrelia burgdorferi is one of the most common vector-borne diseases transmitted by ticks: Acari : Ixodida : Ixodidae belonging to the genus Ixodes $(20,28)$. It has been observed that the number of incidences of LB is increasing in certain European areas which are becoming endemic $(20,26)$. In Poland, the incidence of Lyme disease has increased from 4.79 in 2000 to 55.2 per 100,000 people in $2016(7,8)$.

In Ukraine, LB was officially classified as a group of especially dangerous infections, according to the Regulation of the Minister of Health of Ukraine (N133 of 19.07.1995). Registration of Lyme borreliosis in humans in Ukraine began in 2000. It was proved that the incidence of the disease in the country was growing each year from 58 cases in 2000 (incidence: $0.12 / 100,000)$ to 3413 in 2015 (incidence: 7.96/100,000) (2).

The western part of Ukraine, including the Ternopil area, is recognised as an endemic region for $\mathrm{LB}$, as it is located in the forest-steppe region with mixed forests, fertile soils, as well as adequate moisture and optimal temperatures. Besides these conditions, a variety of plants and animals create favourable conditions for the circulation of the agents of different natural-focal diseases, including LB (12). Accordingly, the number of LB cases in the Ternopil area increased from 2 in 2005 to 115 in $2015(2,12)$ (Fig. 1). 


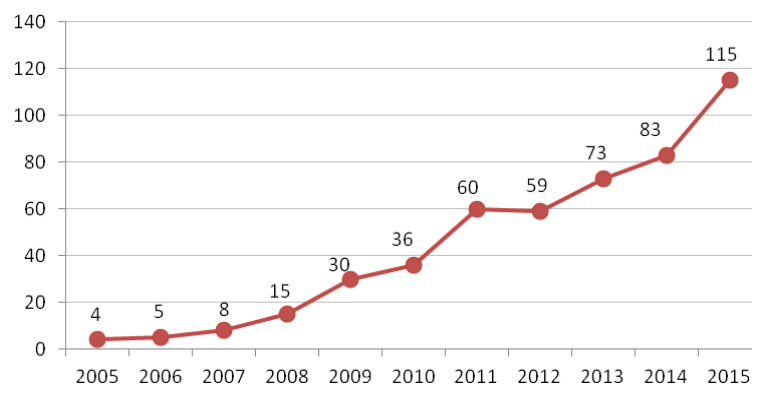

Fig. 1. Number of cases of Lyme borreliosis in Ternopol region (Western Ukraine), in 2005-2015. y axis - number of cases; $\mathrm{x}$ axis - years. (http://realno.te.ua/novyny/на-тернопільщинілютує-страшна- недуг/)

Ixodes ricinus is the vector of Borrelia burgdorferi s.l. in the Ternopil region, where the season of its activity is lengthening each year. In 2005, it lasted from June to October, in 2009 from April to October, in 2010 from May to October, and in 2011 from March to November-December. In 2012, the first ticks in the region were spotted in the last days of February (12). The detection of B. burgdorferi spirochaetes in captured ticks in a particular area is crucial to evaluation of the endemicity of LB, as it enables recognition of the examined area as such. It is also important to identify the percentage of infected ticks because this helps to determine the risk of infection.

The aim of the following study was to evaluate the prevalence of B. burgdorferi s.l. in the ticks of the Ternopil area in Western Ukraine.

\section{Material and Methods}

Study area. The study area was located in the Ternopil Oblast (Western Ukraine) and included the towns Konuchy $\left(49^{\circ} 56^{\prime} \mathrm{N}, 2^{\circ} 06^{\prime} \mathrm{E}\right)$, Biłokrynycia $\left(49^{\circ} 28^{\prime} \mathrm{N}, \quad 25^{\circ} 22^{\prime} \mathrm{E}\right), \quad$ Skala-Podilska $\quad\left(48^{\circ} 85^{\prime} \mathrm{N}\right.$, $\left.26^{\circ} 20^{\prime} \mathrm{E}\right), \quad$ Papirnya $\left(49^{\circ} 13^{\prime} \mathrm{N}, \quad 25^{\circ} 77^{\prime} \mathrm{E}\right)$, and Monastyryska $\left(49^{\circ} 09^{\prime} \mathrm{N}, 25^{\circ} 17^{\prime} \mathrm{E}\right)$. The location of these towns and their environmental conditions are conducive to the occurrence of ticks. Monastyryska is a town situated on the river Koropets, $15 \mathrm{~km}$ from Buchach, $140 \mathrm{~km}$ south east of Lviv, on the road between Ternopil or Berezhany and Ivano-Frankivsk. The river Koropets forms a wide lake. Koniukhy is a village in the Kozova Raion located on the Korsa and Koniukhy rivers. Skala-Podilska or Skala upon Zbruch is an urban-type settlement in Ternopil Oblast on the Zbruch River.

Ticks. The ticks were collected using the flagging method from various places in the Ternopil area between June and July 2016, as described in detail by Komoń and Sytykiewicz (13). The data on the collection locations and tick numbers are presented in
Table 1. The ticks were stored in $70 \%$ ethanol epinephrine at $6^{\circ} \mathrm{C}$ and rinsed in fresh $70 \%$ ethanol before the DNA extraction (11). The identification of the species and their developmental form was based on morphological characteristics based on the differential keys showed by Buczek (3) (Fig. 2).

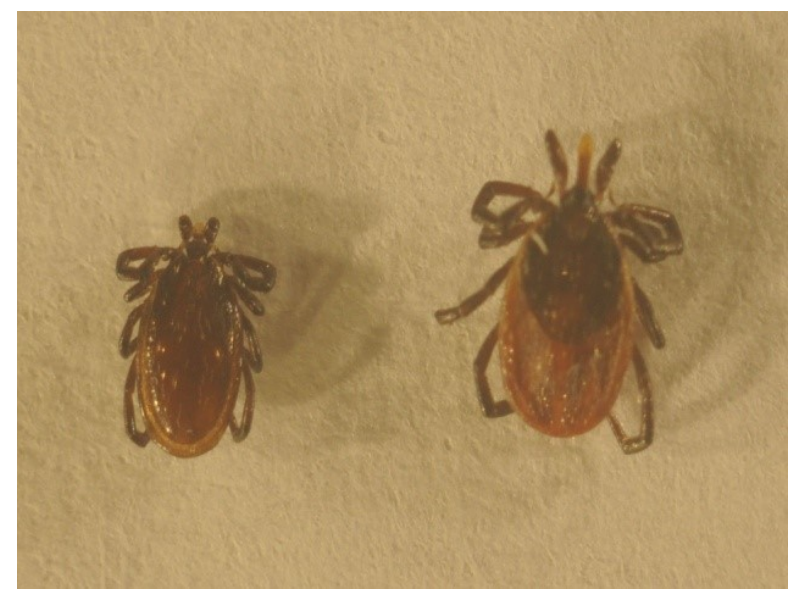

Fig. 2. Ixodes ricinus: male on the left, female on the right

Bacterial reference strains and growth conditions. B. burgdorferi s.s. B31 (ATCC 35210) was used as the reference strain. A $0.1 \mathrm{~mL}$ volume of each strain was inoculated into $5 \mathrm{~mL}$ of BSK-H Complete Medium (Sigma-Aldrich, USA) and incubated in a 5\% $\mathrm{CO}_{2}$ atmosphere at $35^{\circ} \mathrm{C}$ for seven days, to a final cell density of $10^{7} / \mathrm{mL}$ (16). The growth of the bacteria was observed under dark field microscopy.

The isolation of the DNA. The DNA isolation was performed with a QIAamp DNA Mini Kit (Qiagen, Switzerland). The isolated DNA was stored at $-20^{\circ} \mathrm{C}$.

PCR amplification. B5S-Bor (5'GAGTTCGCG GGAGAGTAGGTTATT-3') and 23S-Bor (5'- TCAG GGTACTTAGATGGTTCACTT-3') primers targeting the intergenic spacer $5 S 23 S$ rDNA of B. burgdorferi were used for PCR amplification (1). A mixture of 12.5 $\mu \mathrm{L}$ of StartWarm HS-PCRMix (A\&A Biotechnology, Poland), $2 \mu \mathrm{L}$ of $100 \mu \mathrm{M}$ of each primer, $5 \mu \mathrm{L}$ of extracted DNA, and $3.5 \mu \mathrm{L}$ of $\mathrm{H}_{2} \mathrm{O}$ was used. The PCR was performed in a SensoQuest Thermocycler (SensoQuest, Germany). The following amplification parameters were used: initial denaturation at $94^{\circ} \mathrm{C}$ for $3 \mathrm{~min}, 30$ cycles comprising denaturation at $94^{\circ} \mathrm{C}$ for $20 \mathrm{~s}$, annealing at $52^{\circ} \mathrm{C}$ for $30 \mathrm{~s}$, and extension at $72^{\circ} \mathrm{C}$ for $30 \mathrm{~s}$, and final extension at $72^{\circ} \mathrm{C}$ for $7 \mathrm{~min}$ (11). Positive (B. burgdorferi sensu stricto strain B31 (ATCC 35210)) and negative (sterile deionised water) controls were included. The separation of the specific DNA amplicons was performed using horizontal gel electrophoresis $(1.5 \%$ agarose, $6 \mathrm{~V} / \mathrm{cm}$, over $25 \mathrm{~min})$. Detection of DNA fragments was achieved with Green DNA GelStain (Syngen, Poland) and UV transillumination. The expected size of the 
amplification products was approximately 410 base pairs.

Nucleotide sequence analysis. The obtained DNA amplicons were purified with a Gel-Out concentrator kit (A\&A Biotechnology, Poland). The sequencing reactions (primer 23S-Bor) were carried out by Genomed (Poland). Comparison of sequences to those in the GenBank database was made using the Basic Local Alignment Search Tool (BLASTn), available at the National Center for Biotechnology Information (Maryland, USA).

\section{Results}

The study was conducted on 136 ticks, including: 126/136 (93\%) adults (70/136 females and 56/136 males) and 10/136 (7\%) nymphs. The data on the collection locations and tick numbers are presented in Table 1 .

All the ticks tested belonged to the I. ricinus species. The DNA of Borrelia burgdorferi s. l. was present in 6/136 ticks (4.4\%): 3 females (2.2\%), 2 males $(1.5 \%$, and 1 nymph $(0.7 \%)$ (Table 2$)$.

Most of the infected ticks came from Monastyria (two females, one male, one nymph), Konucha (one female), and Sala-Podilska (one male).

The separated DNA bands from positive samples were used for further procedures. DNA bands were cut out of the gel as a slice, dissolved, and purified (Fig. 3).

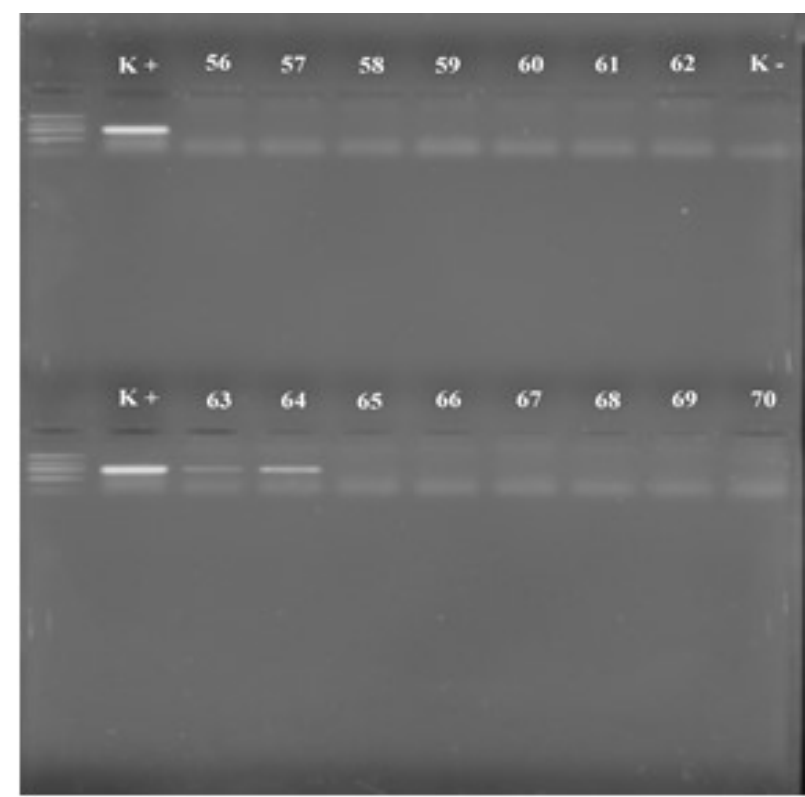

Fig. 3. Electrophoresis gel (K+ positive control, $\mathrm{K}-$ negative control, 56-70 test samples, 63-64 positive samples)

The purified DNA was sequenced and the results are presented in the fluorogram. The sequences obtained after analysing the fluorograms were compared with the sequences amassed in GenBank (Fig. 4).

Table 1. Number of the tested ticks and the place of collection

\begin{tabular}{llllll}
\hline \multirow{2}{*}{$\begin{array}{l}\text { Area } \\
\text { (Western Ukraine) }\end{array}$} & \multicolumn{4}{c}{ Number of Ixodes ricinus ticks } \\
\cline { 2 - 6 } & & Female & Male & Nymph & Total \\
\hline & Konuchy & 17 & 9 & 0 & 26 \\
\cline { 2 - 6 } Ternopil Oblast & Biłokrynycia & 19 & 6 & 0 & 25 \\
\cline { 2 - 6 } & Skala-Podilska & 4 & 21 & 4 & 29 \\
\cline { 2 - 6 } & Papirnya & 15 & 10 & 0 & 25 \\
\cline { 2 - 6 } & Monastyryska & 15 & 10 & 6 & 31 \\
\hline \multirow{2}{*}{ Total } & 70 & 56 & 10 & 136 \\
\hline
\end{tabular}

Table 2. Number and percentage of ticks infected with Borrelia burgdorferi s. $l$.

\begin{tabular}{lll}
\hline Gender and form & Number of ticks & Number and \% of infected ticks \\
\hline Nymph & 10 & $1(10 \%)$ \\
\hline Male & 56 & $2(3.6 \%)$ \\
\hline Female & 70 & $3(4.3 \%)$ \\
\hline Total & 136 & $6(4.4 \%)$ \\
\hline
\end{tabular}




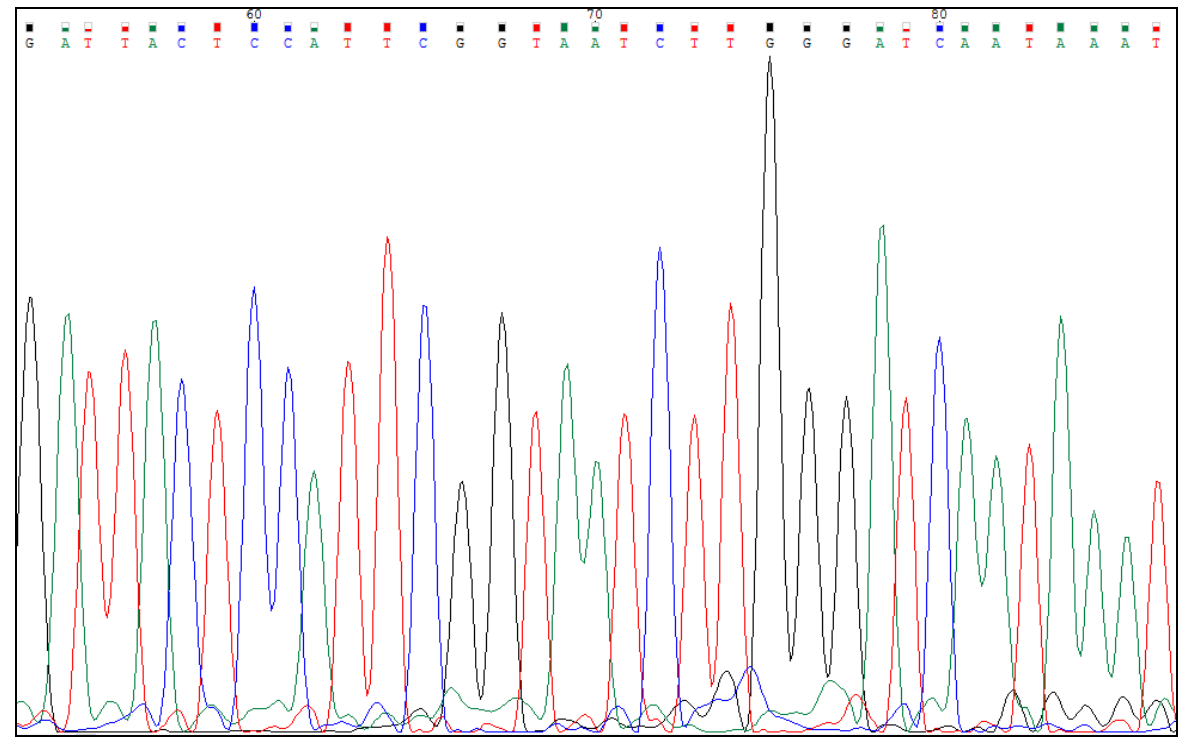

Fig. 4. Fragment of the fluorogram in Borrelia afzelii DNA sequencing

In Borrelia-positive samples, the presence of one genospecies - B. afzelii was detected. The DNA sequencing resulted in $B$. afzelii identification in four samples $(2.9 \%)$. The remaining two samples $(1.5 \%)$ confirmed that Borrelia species belonged to the B. burgdorferi s.l. complex, without identifying the genospecies. It is possible that in these cases difficulty in identifying the species of pathogen was due to infection of ticks by several species of Borrelia.

\section{Discussion}

The prevalence of B. burgdorferi s.l. in ticks is one of the most essential components of risk assessment for LB. Rizzoli et al. (21) showed that B. burgdorferi s.l. in I. ricinus ticks collected in urban parks, gardens, or suburban habitats is distributed approximately at the same rate as in I. ricinus ticks living in forests. Therefore, the risk of contracting LB in urban areas could be as high as in rural environments. Rauter and Hartung (18) evaluated the overall rate of $B$. burgdorferi s.l. in I. ricinus ticks in Europe. The prevalence was calculated on the basis of the results published between 1984 and 2003. It was found that the prevalence of Borrelia in ticks was $13.7 \%$. The rate of infection of adult ticks $(18.6 \%)$ was significantly higher than that of nymphs $(10.1 \%)$. The highest rates of infection of I. ricinus were found in Central Europe (Austria, the Czech Republic, Southern Germany, Switzerland, Slovakia, and Slovenia).

The studies conducted in selected European countries published after 2003 show varying percentages of $I$. ricinus ticks infected with B. burgdorferi ranging from $7.6 \%$ to $42.5 \%(9,15,18$, 19). A large variation in the percentage of $I$. ricinus ticks infected with B. burgdorferi was also observed in Western European countries adjacent to Western
Ukraine: Belarus (14.1\%) (19), Poland (6.8\%-22\%) $(11,23,24)$, Slovakia $(10.2 \%-30.2 \%)(16,22)$, and Romania (18.0\%-25.8\%) $(6,17)$.

In our research conducted on $I$. ricinus ticks collected in the Ternopil area, the DNA of B. burgdorferi s.l. was found in $4.4 \%$ of tested specimens. A similar infected proportion was shown in the study on the ticks collected in seven urban parks and one suburban oak wood park in Kyiv (Northern Ukraine), i.e. $4 \%(28 / 696 ; 27$ adults, 1 nymph) of I. Ricinus infected with B. burgdorferi s.l. complex (10). High rates of infected ticks were found in the study on specimens of $I$. ricinus and $D$. reticulatus collected in the north-western region of Ukraine in the years 1998-2011. B. burgdorferi s.l. was identified in $19.8 \%$ of $I$. ricinus and $3.8 \%$ of $D$. reticulatus ticks. The highest prevalence of infected I. ricinus $(25.0 \%)$ was identified in the Kivertsi, Ratne (19.3\%), and Manevychi (16.7\%) districts, whereas the lowest were reported in Turiysk (6.7\%) (12).

The complex of closely related species of the Borrelia genus transmitted by ticks are referred to as B. burgdorferi s.l., which includes 20 genospecies (14, 25). Rauter and Hartung (18) calculated the overall ratio of $B$. burgdorferi genospecies in I. ricinus ticks in Europe. The most common genospecies were $B$. afzelii (38\%), B. garinii (33\%), B. burgdorferi s.s. (18\%), B. valaisiana (19\%), and B. lusitaniae (7\%), but their distribution varied depending on the region. Our results confirmed that $B$. afzelii genospecies was dominant in the Ternopil area. Similar results were obtained in the urban parks of Kyiv in Northern Ukraine, where B. afzelii was identified in $96.42 \%$ (27/28) of Borreliapositive ticks. Only one $I$. ricinus tick from the Syrets arboretum was infected with $B$. garinii, 3.57\% (1/28) (10). The dominance of $B$. afzelii genospecies was also found in a three-year study (2011-2013) of the population of $I$. ricinus in the Czech Republic (9). 
B. afzelii was the dominant genospecies, followed by $B$. garinii and B. burgdorferi s.s. In the research on ticks removed from humans, the most common genospecies was again $B$. afzelii $(70.0 \%)$, trailed by B. garinii (10.0\%), B. valaisiana (8.6\%), B. spielmanii $(7.1 \%)$, and B. burgdorferi s. s. (4.3\%) (3). The dominance of $B$. afzelii, followed by $B$. garinii, B. burgdorferi s.s., B. valaisiana, and B. lusitaniae was also demonstrated in the ticks from Belarus which borders the north-western part of Ukraine (19). Romania, which borders Ukraine in the south, yielded study data on ticks in which the genospecies $B$. afzelii prevailed $(61.1 \%)$, with $B$. garinii $(31.2 \%)$ the next most prevalent, and B. valaisiana (7.7\%) after that (6). However, in later studies, conducted in Eastern Romania, the predominant genospecies turned out to be $B$. garinii, with (in order of decreasing prevalence) B. afzelii, B. valaisiana, B. lusitaniae, B. miyamotoi, B. burgdorferi s. s, and B. bissettii also featuring (17).

On the other hand, a study on ticks in Eastern Poland, bordering Ukraine in the west, showed that B. burgdorferi s.s. predominated over B. afzelii. In the ticks from the Roztocze National Park in South-Eastern Poland, the genospecies B. burgdorferi s.s. was found in $55.3 \%$ of the ticks infected with B. burgdorferi s.l., whereas the genospecies $B$. afzelii was confirmed in $38.3 \%$ (4). Similar results were obtained in studies conducted in Eastern Poland (Lublin Province). B. burgdorferi s.s. was found in a total of $62.8 \%$ of I. ricinus ticks infected with $B$. burgdorferi s.l., whereas $B$. afzelii and $B$. garinii were less frequent and observed in $39.8 \%$ and $17.7 \%$ of the infected ticks, respectively (5).

In conclusion, the research confirmed the dominance of $B$. afzelii genospecies in the Ternopil area. It seems reasonable to undertake similar research in other regions. Knowledge in this field can be useful for public health and planning the prevention of tickborne diseases, including Lyme disease.

Conflict of Interests Statement: The authors declare that there is no conflict of interests regarding the publication of this article.

Financial Disclosure Statement: This study was supported by the State School of Higher Education in Biala Podlaska, Poland, grant number FG- IV-2015.

Animal Rights Statement: None required.

\section{References}

1. Alekseev A., Dubinina H., van de Pol I., Schouls L.: Identification of Erlichia spp. and Borrelia burgdorferi in Ixodes ticks in the Baltic Region of Russia. J Clin Microbiol 2001, 39, 2237-2242.

2. Andreychyn M., Pańczuk A., Shkilna M., Tokarska-Rodak M., Korda M., Kozioł-Montewka M., Klishch M.: Epidemiological situation of Lyme borreliosis and diagnosis standards in Poland and Ukraine. Health Prob Civil 2017, 11, 190-194.

3. Buczek A.: Atlas pasożytów człowieka. Koliber, Lublin, 2005, pp. 115-170.

4. Cisak E., Chmielewska-Badora J., Zwoliński J., Wójcik-Fatla A., Polak J., Dutkiewicz J.: Risk of tick-borne bacterial disease among workers of Roztocze National Park (South-Eastern Poland). Ann Agric Environ Med 2005, 12, 127-132.

5. Cisak E., Wójcik-Fatla A., Stojek N.M., Chmielewska-Badora J., Zwoliński J., Buczek A., Dutkiewicz J.: Prevalence of Borrelia burgdorferi genospecies in Ixodes ricinus ticks from Lublin region (eastern Poland). Ann Agric Environ Med 2006, 13, 301-306.

6. Coipan E.C., Vladimirescu A.F.: Ixodes ricinus ticks (Acari: Ixodidae): vectors for Lyme disease spirochetes in Romania. Exp Appl Acarol 2011, 54, 293-300.

7. Czarkowski M.P., Cielebąk E., Staszewska-Jakubik E., Kondej B.: Infectious diseases and poisonings in Poland in 2016. National Institute of Public Health, National Institute of Hygiene, Department of Epidemiology. http://wwwold.pzh. gov.pl/oldpage/epimeld/2016/Ch_2016.pdf, 2018.05.30.

8. Czarkowski M.P., Cielebąk E., Stępień E., Kondej B.: Infectious diseases and poisonings in Poland in 2001. National Institute of Hygiene, National Research Center of Public Health Department of Epidemiology. http://wwwold.pzh.gov.pl/ oldpage/epimeld/2001/Ch_2001.pdf, 2018.05.30.

9. Daniel M., Rudenko N., Golovchenko M., Danielová V., Fialová A., Křŕž B., Malý M.: The occurrence of Ixodes ricinus ticks and important tick-borne pathogens in areas with high tickborne encephalitis prevalence in different altitudinal levels of the Czech Republic Part II. Ixodes ricinus ticks and genospecies of Borrelia burgdorferi sensu lato complex. Epidemiol Mikrobiol Imunol 2016, 182-192.

10. Didyk Y.M., Blaňárová L., Pogrebnyak S., Akimov I., Pet'ko B.B., Víchová B.: Emergence of tick-borne pathogens (Borrelia burgdorferi sensu lato, Anaplasma phagocytophilum, Ricketsia raoultii, and Babesia microti) in the Kyiv urban parks, Ukraine. Ticks Tick Borne Dis 2017, 8, 219-225.

11. Dunaj J., Zajkowska J., Kondrusik M., Gern L., Rais O., Moniuszko A., Pancewicz S., Świerzbińska R.: Borrelia burgdorferi genospecies detection by RLB hybridization in Ixodes ricinus ticks from different sites of North-Eastern Poland. Ann Agric Environ Med 2014, 21, 239-243.

12. Fedonyuk L.Y., Chaban G.P., Rybitska L.N., Avsyukevich A.S.: Epidemiological characteristics, clinical and diagnostic peculiarities of the systemic tick-borne Lyme in Ternopil region. Taurian Med Biol J 2013, 16, 198-202.

13. Komoń T., Sytykiewicz H.: Occurrence of Borrelia burgdorferi s.l. in selected Ixodes ricinus populations within Nadbużański Landscape Park. Wiad Parazytol 2007, 53, 309-317.

14. Margos G., Fedorova N., Kleinjan J.E., Hartberger C., Schwan T.G., Sing A., Fingerle V.: Borrelia lanei sp. nov. extends the diversity of Borrelia species in California. Int J Syst Evol Microbiol 2017, 67, 3872-3876.

15. Moutailler S., Valiente Moro C., Vaumourin E., Michelet L., Tran F.H., Devillers E., Cosson J.F., Gasqui P., Van V.T., Mavingui P.: Coinfection of ticks: the rule rather than the exception. PLoS Negl Trop Dis 2016, 10 (http://journals. plos.org/plosntds/article?id=10.1371/journal.pntd.0004539, 2018. 05.30.

16. Pangrácová L., Derdáková M., Pekárik L., Hviščová I., Víchová B., Stanko M., Hlavatá H., Pet'ko B.: 2013. Ixodes ricinus abundance and its infection with the tick-borne pathogens in urban and suburban areas of Eastern Slovakia. Parasit Vectors 2013, 6, 238.

17. Raileanu C., Moutailler S., Pavel I., Porea D., Mihalca A.D., Savuta G., Vayssier-Taussat M.: Borrelia diversity and coinfection with other tick borne pathogens in ticks. Front Cell Infect Microbiol 2017, 7, 36. doi: 10.3389/fcimb.2017.00036. 
18. Rauter C., Hartung T.: Prevalence of Borrelia burgdorferi sensu lato genospecies in Ixodes ricinus ticks in Europe: a metaanalysis. Appl Environ Microbiol 2005, 71, 7203-7216.

19. Reye A.L., Stegniy V., Mishaeva N.P., Velhin S., Hubschen J.M., Ignatyev G., Muller C.P.: Prevalence of tick-borne pathogens in Ixodes ricinus and Dermacentor reticulatus ticks from different geographical locations in Belarus. PLoS ONE 2013, e54476. doi:10.1371/journal.pone.0054476.

20. Rizzoli A., Hauffe H.C., Carpi G., Vourc'h G.I., Neteler M., Rosa R.: Lyme borreliosis in Europe. Euro Surveill 2011, 16. http://www.eurosurveillance.org/ViewArticle.aspx?ArticleId=19 906, 2018.05.30

21. Rizzoli A., Silaghi C., Obiegala A., Rudolf I., Hubálek Z., Földvári G., Plantard O., Vayssier-Taussat M., Bonnet S., Špitalská E.: Ixodes ricinus and its transmitted pathogens in urban and peri-urban areas in Europe: New Hazards and Relevance for Public Health. Front Public Health 2014, 2, 251. https://www.frontiersin.org/articles/10.3389/fpubh.2014.00251/f ull, 2018.05.30.

22. Subramanian G., Sekeyova Z., Raoult D., Mediannikov O.: Multiple tick-associated bacteria in Ixodes ricinus from Slovakia. Ticks Tick-borne Dis 2012, 3, 405-409.

23. Sytykiewicz H., Karbowiak G., Werszko J., Czerniewicz P., Sprawka I., Mitrus J.: Molecular screening for Bartonella henselae and Borrelia burgdorferi sensu lato co-existence within Ixodes ricinus populations in central and eastern parts of Poland. Ann Agric Environ Med 2012, 19, 451-456.

24. Sytykiewicz H., Karbowiak G., Chorostowska-Wynimko J., Szpechciński A., Supergan-Marwicz M., Horbowicz M., Szwed M., Czerniewicz P., Sprawka I.: Coexistence of Borrelia burgdorferi s.l. genospecies within Ixodes ricinus ticks from central and eastern Poland. Acta Parasitol 2015, 60, 654-61.

25. Tokarska-Rodak M.: Infections caused by Borrelia burgdorferi sensu lato. Health Prob Civil 2016, 10, 5-9.

26. van den Wijngaard C.C., Hofhuis A., Simões M., Rood E., van Pelt W., Zeller H., van Bortel W.: Surveillance perspective on Lyme borreliosis across the European Union and European Economic Area. Euro Surveill 2017, 27. doi: http://dx.doi.org/ 10.2807/1560-7917.ES.2017.22.27.30569, 2018.05.30.

27. Venclíková K., Betášová L., Sikutová S., Jedličková P., Hubálek Z., Rudolf I.: Human pathogenic Borreliae in Ixodes ricinus ticks in natural and urban ecosystem (Czech Republic). Acta Parasitol 2014, 59, 717-720.

28. Żukiewicz-Sobczak W.A., Chmielewska-Badora J., Wróblewska P.J., Zwoliński J.: Farmers' occupational diseases of allergenic and zoonotic origin. Postep Derm Alerg 2013, 30, 311-315. 